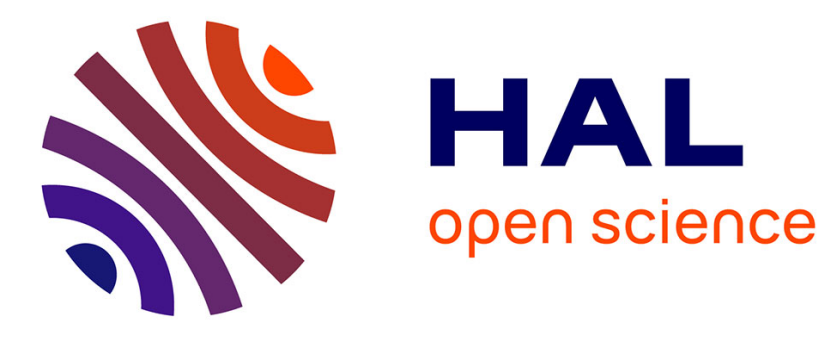

\title{
The flawless immune tolerance of pregnancy
}

Steve Genebrier, Karin Tarte

\section{To cite this version:}

Steve Genebrier, Karin Tarte. The flawless immune tolerance of pregnancy. Joint Bone Spine, 2021, 88 (5), pp.105205. 10.1016/j.jbspin.2021.105205 . hal-03260842

\section{HAL Id: hal-03260842 \\ https://hal.science/hal-03260842}

Submitted on 16 Jun 2021

HAL is a multi-disciplinary open access archive for the deposit and dissemination of scientific research documents, whether they are published or not. The documents may come from teaching and research institutions in France or abroad, or from public or private research centers.
L'archive ouverte pluridisciplinaire HAL, est destinée au dépôt et à la diffusion de documents scientifiques de niveau recherche, publiés ou non, émanant des établissements d'enseignement et de recherche français ou étrangers, des laboratoires publics ou privés. 


\section{The flawless immune tolerance of pregnancy}

Steve Genebrier ${ }^{1,2}$, Karin Tarte ${ }^{1,2}$

1: Unité Inserm U1236, Université de Rennes 1, Rennes, France

2: CHU de Rennes, Pôle Biologie, Rennes, France

Corresponding author: Karin Tarte

INSERM, UMR U1236, Faculté de médecine, 2 avenue du Pr Léon Bernard, 35043 Rennes, France.

Tel.: +330223234512

E-mail address: karin.tarte@univ-rennes1.fr

Keywords: immune tolerance, pregnancy, allorecognition 


\section{Introduction}

For a long time, the process of pregnancy, a physiological state absolutely essential for the survival of viviparous species, caused immunologists to wonder: how is it that a fetus, a semi-allogeneic organism (or even totally allogeneic in cases where the oocyte or embryo is donated), is not rejected by the mother as with an organ transplant? As early as in 1945, Ray Owen observed that two dizygotic calves that shared the same circulatory system in utero were able to tolerate the other's blood group as an adult [1], thus revealing the plasticity of the immune response in a gestational context. A few years later, Peter Medawar, who went on to win the Nobel prize in physiology, proposed the concept of "fetal tolerance" to describe the way a mother adapts to her child [2]. This paradigm has been confirmed by dissecting the different mechanisms involved, in particular by using murine models. Indeed, despite the many maternal-fetal interfaces created during pregnancy, and the very high level of contact between the cells of the two organisms, active phenomena provide selective maternal tolerance towards her fetus without compromising her ability to defend against infectious agents. This field of study has even shown, conversely, the central role of the immune system at all stages of pregnancy, from implantation to birth.

In this review, we will describe the main immunological elements involved in a positive pregnancy outcome.

\section{Role of the immune system in placentation}

In what are known as eutherian or placental mammals, the fetus is separated from the mother by the amniotic fluid and the placenta, tissue derived from the trophectoderm of the blastocyst [3]. The placenta is the most important maternal-fetal interface: it performs essential metabolic functions such as gas and nutrient exchange, waste elimination and the synthesis of progesterone - a hormone essential to maintain pregnancy [4]. The development of this structure, in direct contact with the mother's blood, is afforded extraordinary immunological benefits.

\subsection{Structure of the placenta}

In both humans and mice, placentation is haemochorial, meaning that the placenta invades the maternal uterine tissue [3]. The blastocyst becomes implanted in the decidua, an endometrial structure that only exists during pregnancy [5]. Placental trophoblasts colonize the decidua to form villous trees, which will collect in the umbilical cord (Fig 1). The remodelling of uterine arteries into flaccid spiral arteries will slow down the maternal blood in which the placental villi bathe, and thus facilitate metabolic exchanges [6].

\subsection{Maternal leukocytes and decidual remodelling}

The remodelling of the decidual arteries is not only due to trophoblasts. In fact, a maternal leukocyte population found only during pregnancy contributes to this phenomenon, decidual NK (natural killer) cells [7]. Circulating NK cells are a population of innate lymphocytes, overwhelmingly of the $\operatorname{CD} 56^{\mathrm{dim}} \mathrm{CD} 16^{+}$phenotype, which typically exhibit cytotoxic properties when the signals delivered by their activating receptors exceed those generated by their inhibitory receptors [8]. However, decidual NK cells exhibit very different characteristics to circulating NK cells. Of the $\mathrm{CD} 56^{\text {bright }} \mathrm{CD} 16^{\text {dim }}$ phenotype, they are only slightly cytotoxic and, on the contrary, exhibit tissue homeostasis functions by secreting growth factors, angiogenic factors, and cytokines [9]. Their abundance is highest in the first trimester (70\% of decidual leukocytes) [7]. The trophic role of these cells is supported by murine models where their absence is associated with decreased fetal survival [10]. In humans, a much lower percentage of decidual NK cells has been observed in endometrial biopsies from women with unexplained infertility compared to biopsies from fertile women [11]. A recent study demonstrated the presence of a particular subtype of decidual NK cells in multiparous women [12]. These "pregnancy-trained" cells have greater IFN- $\gamma$ and VEGF $\alpha$ production capacities and are thought to facilitate implantation in subsequent pregnancies from the same father.

\section{Maternal tolerance mechanisms}


Many mechanisms, mainly targeting the activation of T cells, contribute to maternal tolerance towards the fetus (Fig 2). None are sufficient on their own, and while some are more important than others, it is their accumulation that enables the normal course of pregnancy. As we will see, every step of immune system activation is inhibited.

\subsection{Activation and recruitment of T cells}

To be activated, a naive T cell must recognize its specific antigen presented as peptide-MHC complexes on mature dendritic cells [13]. Typically, dendritic cells take up antigens in peripheral tissues and migrate to the draining lymph nodes [14]. First of all, it should be noted that, in pregnancy, maternal T cells are only activated by fetal antigens through indirect allorecognition $[15,16]$, that is to say that it is the maternal dendritic cells that will present the antigens. The fetus may therefore activate only a small fraction of its mother $\mathrm{T}$ cells, much less than when direct allorecognition is involved, as is the case with organ transplants [17]. In addition, the endometrium appears to be devoid of lymphatic vessels, thus preventing the activation of T cells in this way. While this histological characteristic has been confirmed in mice [18], it is still debated in humans $[19,20]$. Regardless, decidual dendritic cells are stuck in a tolerogenic state [21] meaning that if they do manage to reach a lymph node, they cannot effectively activate $T$ cells.

However, the activation of fetal antigen-specific T cell clones remains possible via the systemic pathway due to the release of placental debris into the maternal circulation system [22]. This diffusion into the circulation is limited by decidual macrophages, which eliminate some of the apoptotic cells from trophoblasts $[23,24]$. Their clearance limits inflammation and helps these macrophages acquire a tolerogenic phenotype [24].

An additional mechanism, this time obstructing the local recruitment of activated lymphocytes, has been demonstrated in mice. One study showed epigenetic silencing of decidual stromal cell expression of CXCL9 and CXCL10, chemokines responsible for the recruitment of Th1 (CXCR3 $\left.{ }^{+}\right)$lymphocytes [25]. It is not yet known whether such a mechanism is active in humans.

\subsection{Limited MHC molecule expression}

MHC molecule expression is repressed in the placenta, which greatly reduces allorecognition: MHC class I molecules are only poorly expressed [26] and MHC class II molecules are not inducible [27]. Extravillous trophoblasts express only HLA-C molecules [26], which prevents their lysis by decidual NK cells through "missing self recognition" [28]. Indeed, MHC class I molecules, and particularly those of the HLA-C locus, are recognized by inhibitory KIR (killer-cell immunoglobulin-like receptors) and therefore prevent the activation of NK cells $[8,28]$. Certain HLA-C/KIR combinations appear to be unfavourable and increase the risk of pre-eclampsia, which underlines the vital role of HLA-C in the regulation of decidual NK cells [29].

Certain less polymorphic non-classical MHC class I molecules, mainly involved in the regulation of immune responses rather than in the presentation of non-self antigens [30], also allow extravillous trophoblasts to escape immunosurveillance with decidual NK cells by binding to various inhibitory receptors. This is the case with HLA-E [31] and HLA-G $[32,33]$ molecules. Note that HLA-G, especially via its soluble form, also plays a role in angiogenesis and remodelling of spiral arteries [34].

\subsection{Local inhibition of T responses}

Placental cells are able to actively defend themselves against activated T cells. For example, the placenta expresses the inhibitory molecule PD-L1 [35]. In addition, syncytiotrophoblasts release exosomes containing TRAIL and FasL, molecules capable of inducing apoptosis through death receptors [36].

Decidual macrophages also limit the activity of T cells by another means: they produce the enzyme IDO (indoleamine 2,3-dioxygenase) which causes the deprivation of tryptophan, an amino acid essential for lymphocyte metabolism, 
by transforming it into an inhibitory catabolite, kynurenine [37]. This enzyme also plays a role in the induction of regulatory T cells.

\subsection{Suppression by regulatory $T$ cells}

The contribution of regulatory T cells (Tregs) to maternal-fetal tolerance has mainly been studied in mice: their depletion increases the risk of fetal loss in non-syngeneic pregnancies [38] while their adoptive transfer decreases it [39].

A very elegant study using a transgenic murine model demonstrated the accelerated expansion of fetal-specific Tregs in the mother [40]. Another study clarified that these were peripherally induced Tregs and not thymic Tregs [41]. Indeed, CNS1-KO mice (CNS1 amplifies the FOXP3 gene essential for the generation of this category of Tregs) have an increased rate of fetal resorption in cases of allogeneic pregnancy but not in cases of syngeneic pregnancy [41]. This research even includes a very interesting phylogenetic component: the CNS1 sequence is highly conserved and is only present in eutherian mammals - it is absent in non-placental mammals such as marsupials and monotremes which underlines the prominent role of induced Tregs in the acquisition of placentation during evolution [41].

Induction of Tregs begins at conception with exposure to paternal antigens in the semen [42, 43]. Fetal microchimerism, the persistent transfer of cells from the infant to the mother, is thought to play a role in the longterm continuation of differentiation into Tregs [44]. Note that the percentage of fetal-specific Tregs cincreases with successive pregnancies from the same father [40], which can be interpreted as an immunological advantage provided by the first child to the siblings.

Despite extensive research, the exact mechanism of action of Tregs in pregnancy has not been determined precisely. The most popular hypothesis is based on the traditional effects of Tregs in the homeostasis of immune response: they prevent fetal loss by inhibiting conventional T cells directed against the fetus and systemic inflammation [45].

\section{Birth and disruption of tolerance}

In recent years, it has been shown that the disruption of maternal-fetal tolerance contributes to the onset of labour, with gestational tissue changing from a quiescent to an inflammatory state [46]. Several immunological obstacles created during pregnancy are thus lifted during childbirth: NK cells are activated, tolerogenic macrophages decreased and MHC molecules expressed by the placenta [47].

\section{Conclusion}

In light of the very specific mechanisms that come into play during pregnancy, it would appear that the fetus is in no way akin to an allogeneic solid organ transplant and that this parallel is therefore no longer relevant. The mother immunological adaptations appear to be essential for a positive pregnancy outcome with regard to conditions associated with deficient tolerance such as pre-eclampsia [48] or miscarriage [49].

However, we should not forget that the fetus also tolerates its mother and that pregnancy is therefore an important time for the ontogenesis of its immune system. The transplacental transfer of maternal immunoglobulins $G$ via the neonatal Fc receptor [50], a mechanism which provides passive humoral protection to the child, automatically comes to mind, especially since the passage of pathogenic antibodies may be responsible for well-known disorders such as haemolytic disease of the newborn or antiphospholipid syndrome [50]. Another less well-characterized phenomenon seems to contribute actively to the education of the fetal immune system: maternal microchimerism. Indeed, maternal cells that cross the placenta and become established in the unborn child are necessary for the maturation of the fetal thymus [44]. This microchimerism could have very long-term consequences, either harmful - it is suspected of being involved in the development of certain adult autoimmune diseases [44] - or beneficial - it would explain the success of haploidentical bone marrow transplants between a mother and her children [51].

\section{Declaration of conflicts of interest}


The authors declare that they have no conflicts of interest.

Page 5 of 9 


\section{$\underline{\text { References }}$}

1. Owen R. Immunogenetic consequences of vascular anastomoses between bovine twins. Science. 1945:400-401.

2. Medawar PB. Some immunological and endocrinological problems raised by the evolution of viviparity in vertebrates. Symposia of the Society for Experimental Biology. 1953:320-338.

3. Moffett A, Loke C. Immunology of placentation in eutherian mammals. Nat Rev Immunol. 2006;6(8):584-594.

4. Malassiné A, Frendo JL, Evain-Brion D. A comparison of placental development and endocrine functions between the human and mouse model. Hum Reprod Update. 2003;9(6):531-539.

5. Norwitz ER, Schust DJ, Fisher SJ. Implantation and the survival of early pregnancy. N Engl J Med. 2001;345(19):1400-1408.

6. Erlebacher A. Immunology of the maternal-fetal interface. Annu Rev Immunol. 2013;31:387-411. doi:10.1146/annurev-immunol-032712-100003

7. Zhang J, Chen Z, Smith GN, Croy BA. Natural killer cell-triggered vascular transformation: maternal care before birth? Cell Mol Immunol. 2011;8(1):1-11.

8. Vivier E, Tomasello E, Baratin M, Walzer T, Ugolini S. Functions of natural killer cells. Nat Immunol. 2008;9(5):503-510.

9. Hanna J, Goldman-Wohl D, Hamani Y, et al. Decidual NK cells regulate key developmental processes at the human fetal-maternal interface. Nat Med. 2006;12(9):1065-1074.

10. Guimond M-J, Wang B, Croy BA. Engraftment of Bone Marrow from Severe Combined Immunodeficient (SCID) Mice Reverses the Reproductive Deficits in Natural Killer Cell-deficient tge26 Mice. Journal of Experimental Medicine. 1998;187(2):217-223.

11. Klentzeris LD, Bulmer JN, Warren MA, Morrison L, Li TC, Cooke ID. Lymphoid tissue in the endometrium of women with unexplained infertility: morphometric and immunohistochemical aspects. Human Reproduction. 1994;9(4):646-652. doi:10.1093/oxfordjournals.humrep.a138564

12. Gamliel M, Goldman-Wohl D, Isaacson B, et al. Trained Memory of Human Uterine NK Cells Enhances Their Function in Subsequent Pregnancies. Immunity. 2018;48(5):951-962.e5. doi:10.1016/j.immuni.2018.03.030

13. Gaud G, Lesourne R, Love PE. Regulatory mechanisms in T cell receptor signalling. Nat Rev Immunol. 2018;18(8):485-497.

14. Worbs T, Hammerschmidt SI, Förster R. Dendritic cell migration in health and disease. Nat Rev Immunol. 2017;17(1):30-48. doi:10.1038/nri.2016.116

15. Erlebacher A, Vencato D, Price KA, Zhang D, Glimcher LH. Constraints in antigen presentation severely restrict $T$ cell recognition of the allogeneic fetus. J Clin Invest. 2007;117(5):1399-1411.

16. Tilburgs T, Scherjon SA, van der Mast BJ, et al. Fetal-maternal HLA-C mismatch is associated with decidual T cell activation and induction of functional T regulatory cells. Journal of Reproductive Immunology. 2009;82(2):148157.

17. Benichou G, Valujskikh A, Heeger PS. Contributions of direct and indirect T cell alloreactivity during allograft rejection in mice. J Immunol. 1999;162(1):352-358. 
18. Moldenhauer LM, Hayball JD, Robertson SA. Utilising T cell receptor transgenic mice to define mechanisms of maternal T cell tolerance in pregnancy. Journal of Reproductive Immunology. 2010;87(1-2):1-13.

19. Böckle BC, Sölder E, Kind S, Romani N, Sepp NT. DC-SIGN+ CD163+ Macrophages Expressing Hyaluronan Receptor LYVE-1 Are Located within Chorion Villi of the Placenta. Placenta. 2008;29(2):187-192.

20. Red-Horse K. Cytotrophoblast induction of arterial apoptosis and lymphangiogenesis in an in vivo model of human placentation. Journal of Clinical Investigation. 2006;116(10):2643-2652.

21. Segerer SE, Rieger L, Kapp M, et al. MIC-1 (a multifunctional modulator of dendritic cell phenotype and function) is produced by decidual stromal cells and trophoblasts. Human Reproduction. 2012;27(1):200-209.

22. Collins MK, Tay C-S, Erlebacher A. Dendritic cell entrapment within the pregnant uterus inhibits immune surveillance of the maternal/fetal interface in mice. J Clin Invest. Published online June 22, 2009:JCI38714.

23. Abrahams VM, Kim YM, Straszewski SL, Romero R, Mor G. Macrophages and Apoptotic Cell Clearance During Pregnancy: DECIDUAL MACROPHAGE FUNCTION DURING PREGNANCY. American Journal of Reproductive Immunology. 2004;51(4):275-282.

24. Abumaree MH, Chamley LW, Badri M, El-Muzaini MF. Trophoblast debris modulates the expression of immune proteins in macrophages: a key to maternal tolerance of the fetal allograft? Journal of Reproductive Immunology. 2012;94(2):131-141.

25. Nancy P, Tagliani E, Tay C-S, Asp P, Levy DE, Erlebacher A. Chemokine Gene Silencing in Decidual Stromal Cells Limits T Cell Access to the Maternal-Fetal Interface. Science. 2012;336(6086):1317-1321.

26. Tilburgs T, Scherjon SA, Claas FHJ. Major histocompatibility complex (MHC)-mediated immune regulation of decidual leukocytes at the fetal-maternal interface. Journal of Reproductive Immunology. 2010;85(1):58-62.

27. Murphy SP, Tomasi TB. Absence of MHC class II antigen expression in trophoblast cells results from a lack of class II transactivator (CIITA) gene expression. Mol Reprod Dev. 1998;51(1):1-12. doi:10.1002/(SICI)10982795(199809)51:1<1::AID-MRD1>3.0.CO;2-L

28. Hilton HG, Parham P. Missing or altered self: human NK cell receptors that recognize HLA-C. Immunogenetics. 2017;69(8-9):567-579.

29. Moffett A, Colucci F. Uterine NK cells: active regulators at the maternal-fetal interface. J Clin Invest. 2014;124(5):1872-1879.

30. Morandi F, Pistoia V. Interactions between HLA-G and HLA-E in Physiological and Pathological Conditions. Front Immunol. 2014;5. doi:10.3389/fimmu.2014.00394

31. King A, Allan DS, Bowen M, et al. HLA-E is expressed on trophoblast and interacts with CD94/NKG2 receptors on decidual NK cells. Eur J Immunol. 2000;30(6):1623-1631. doi:10.1002/1521-4141(200006)30:6<1623::AIDIMMU1623>3.0.CO;2-M

32. Rajagopalan S, Long EO. A Human Histocompatibility Leukocyte Antigen (HLA)-G-specific Receptor Expressed on All Natural Killer Cells. Journal of Experimental Medicine. 1999;189(7):1093-1100.

33. Apps R, Gardner L, Sharkey AM, Holmes N, Moffett A. A homodimeric complex of HLA-G on normal trophoblast cells modulates antigen-presenting cells via LILRB1. Eur J Immunol. 2007;37(7):1924-1937.

34. Xu X, Zhou Y, Wei H. Roles of HLA-G in the Maternal-Fetal Immune Microenvironment. Front Immunol. 2020;11:592010. 
35. Petroff MG, Kharatyan E, Torry DS, Holets L. The Immunomodulatory Proteins B7-DC, B7-H2, and B7-H3 Are Differentially Expressed across Gestation in the Human Placenta. The American Journal of Pathology. 2005;167(2):465-473.

36. Stenqvist A-C, Nagaeva O, Baranov V, Mincheva-Nilsson L. Exosomes Secreted by Human Placenta Carry Functional Fas Ligand and TRAIL Molecules and Convey Apoptosis in Activated Immune Cells, Suggesting Exosome-Mediated Immune Privilege of the Fetus. JI. 2013;191(11):5515-5523.

37. Vacca $\mathrm{P}$, Cantoni $\mathrm{C}$, Vitale $\mathrm{M}$, et al. Crosstalk between decidual NK and CD14+ myelomonocytic cells results in induction of Tregs and immunosuppression. Proc Natl Acad Sci U S A. 2010;107(26):11918-11923.

38. Aluvihare VR, Kallikourdis M, Betz AG. Regulatory T cells mediate maternal tolerance to the fetus. Nat Immunol. 2004;5(3):266-271.

39. Zenclussen AC, Gerlof K, Zenclussen ML, et al. Regulatory T cells induce a privileged tolerant microenvironment at the fetal-maternal interface. Eur J Immunol. 2006;36(1):82-94.

40. Rowe JH, Ertelt JM, Xin L, Way SS. Pregnancy imprints regulatory memory that sustains anergy to fetal antigen. Nature. 2012;490(7418):102-106.

41. Samstein RM, Josefowicz SZ, Arvey A, Treuting PM, Rudensky AY. Extrathymic generation of regulatory T cells in placental mammals mitigates maternal-fetal conflict. Cell. 2012;150(1):29-38. doi:10.1016/j.cell.2012.05.031

42. Moldenhauer LM, Diener KR, Thring DM, Brown MP, Hayball JD, Robertson SA. Cross-Presentation of Male Seminal Fluid Antigens Elicits T Cell Activation to Initiate the Female Immune Response to Pregnancy. J Immunol. 2009;182(12):8080-8093.

43. Guerin LR, Moldenhauer LM, Prins JR, Bromfield JJ, Hayball JD, Robertson SA. Seminal Fluid Regulates Accumulation of FOXP3+ Regulatory T Cells in the Preimplantation Mouse Uterus Through Expanding the FOXP3+ Cell Pool and CCL19-Mediated Recruitment1. Biology of Reproduction. 2011;85(2):397-408.

44. Kinder JM, Stelzer IA, Arck PC, Way SS. Immunological implications of pregnancy-induced microchimerism. Nat Rev Immunol. 2017;17(8):483-494.

45. Erlebacher A. Mechanisms of T cell tolerance towards the allogeneic fetus. Nat Rev Immunol. 2013;13(1):23-33.

46. Menon R, Bonney EA, Condon J, Mesiano S, Taylor RN. Novel concepts on pregnancy clocks and alarms: redundancy and synergy in human parturition. Hum Reprod Update. 2016;22(5):535-560.

47. Marcellin L, Schmitz T, Messaoudene M, et al. Immune Modifications in Fetal Membranes Overlying the Cervix Precede Parturition in Humans. J Immunol. 2017;198(3):1345-1356.

48. Fisher SJ. Why is placentation abnormal in preeclampsia? Am J Obstet Gynecol. 2015;213(4 Suppl):S115-122.

49. Kheshtchin N, Gharagozloo M, Andalib A, Ghahiri A, Maracy MR, Rezaei A. The Expression of Th1- and Th2Related Chemokine Receptors in Women with Recurrent Miscarriage: the Impact of Lymphocyte Immunotherapy. American Journal of Reproductive Immunology. Published online March 2010. doi:10.1111/j.1600-0897.2010.00829.x

50. Palmeira P, Quinello C, Silveira-Lessa AL, Zago CA, Carneiro-Sampaio M. IgG Placental Transfer in Healthy and Pathological Pregnancies. Clinical and Developmental Immunology. 2012;2012:1-13.

51. Ichinohe T. Long-term feto-maternal microchimerism revisited: Microchimerism and tolerance in hematopoietic stem cell transplantation. Chimerism. 2010;1(1):39-43. 


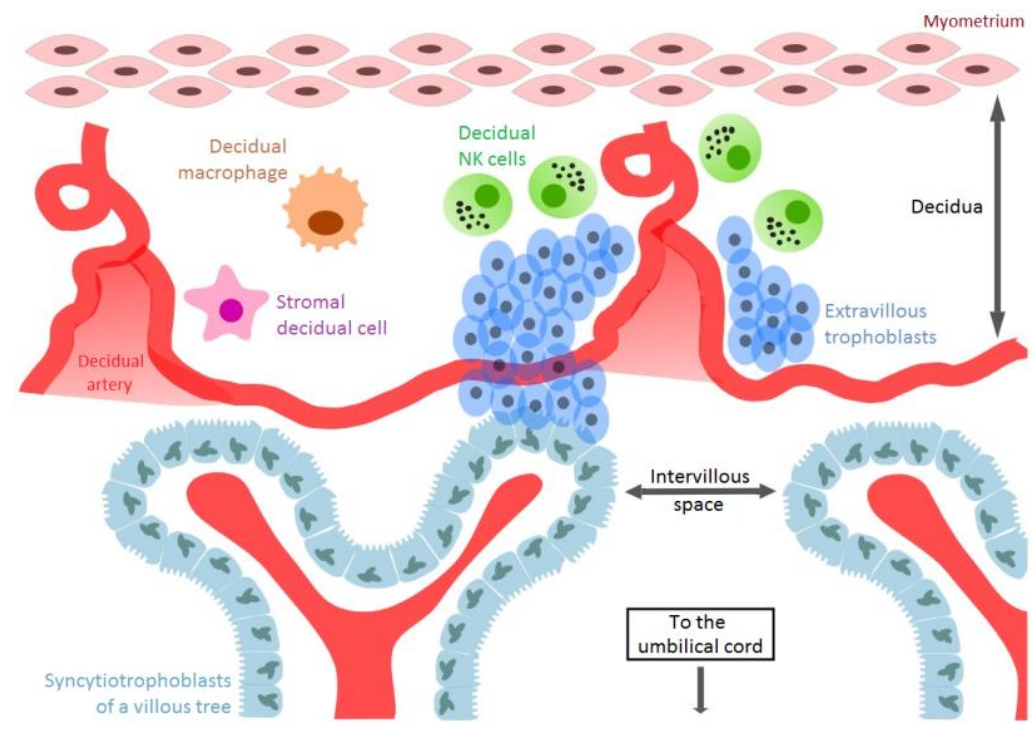

Fig 1. Maternal-fetal interfaces.

Extravillous trophoblasts invade the decidua and contribute to the remodelling of the uterine arteries with the help of macrophages and decidual NK cells. The chorionic villi are bathed by the maternal blood. Note that maternal and fetal blood cells are separated by syncytiotrophoblasts and are therefore not in direct contact. Here the placenta is represented in its hemomonochorial form, that is, made up of a single layer of syncytiotrophoblasts. In the first trimester, there is an underlying layer of mononuclear trophoblasts but this disappears in the second trimester.

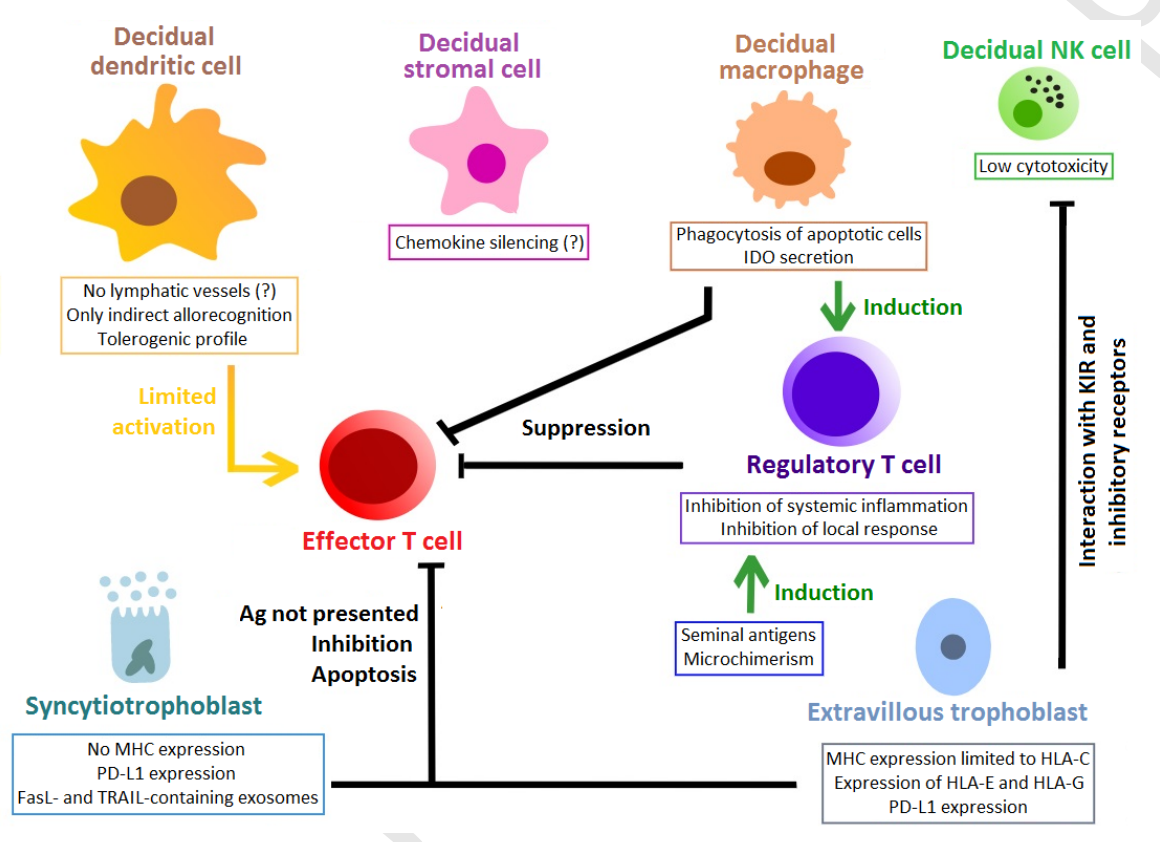

Figure 2. Diagram summarizing the mechanisms of maternal fetal tolerance.

Abbreviations: Ag, antigens; IDO, indoleamine 2,3 dioxygenase; KIR: killer immunoglobulin-like receptors. The question marks indicate mechanisms only described in mice. 